ADALAH : Buletin Hukum \&

Keadilan

@adalahuinjkt

\title{
Komunikasi Politik Pemerintah Indonesia dan Rusia Dalam Meredam Politik Identitas
}

\author{
Zahrotunnimah*
}

Sejarah mencatat adanya hubungan dekat antara Indonesia dan Uni soviet, bahkan Prof Guber menuliskan nama Indonesia dalam bukunya pada tahun 1933, sedang nama Indonesia pada saat itu masih terbatas digunakan pada kalangan pejuang Indonesia saja, akan tetapi Guber telah tuliskan dalam buku tersebut, walaupun saat itu Indonesia masih bernama Hindia Belanda.

Hubungan antara Indonesia dan Uni Soviet juga terlihat ketika pada tahun 1945, ketika Indonesia memproklamasikan

kemerdekaannya dan melancarkan perang melawan kolonialisme. Pada akhirnya kemenangan berpihak pada Rakyat Indonesia yakni kemerdekaan Indonesia. Dalam hal ini pengakuan dari komunitas internasional menjadi sangat penting. Kemudian mulai muncul berbagai dukungan dari berbagai komunitas International seperti Uni Soviet, Ukraina, Belarus, dan sekutu -sekutu Rusia di PBB dan mengecam keras agresi Belanda terhadap Indonesia.

Tahun 1948 Uni soviet berupaya membuka hubungan diplomatik pertama dengan pemerintah Republik Indonesia. Penawaran hubungan diplomatik ini disambut baik oleh Indonesia bahkan kedua negara pernah melakukan pertemuan dan kesepakatan di Praha, akan tetapi hasil kesepakatan tersebut akhirnya dibatalkan karena

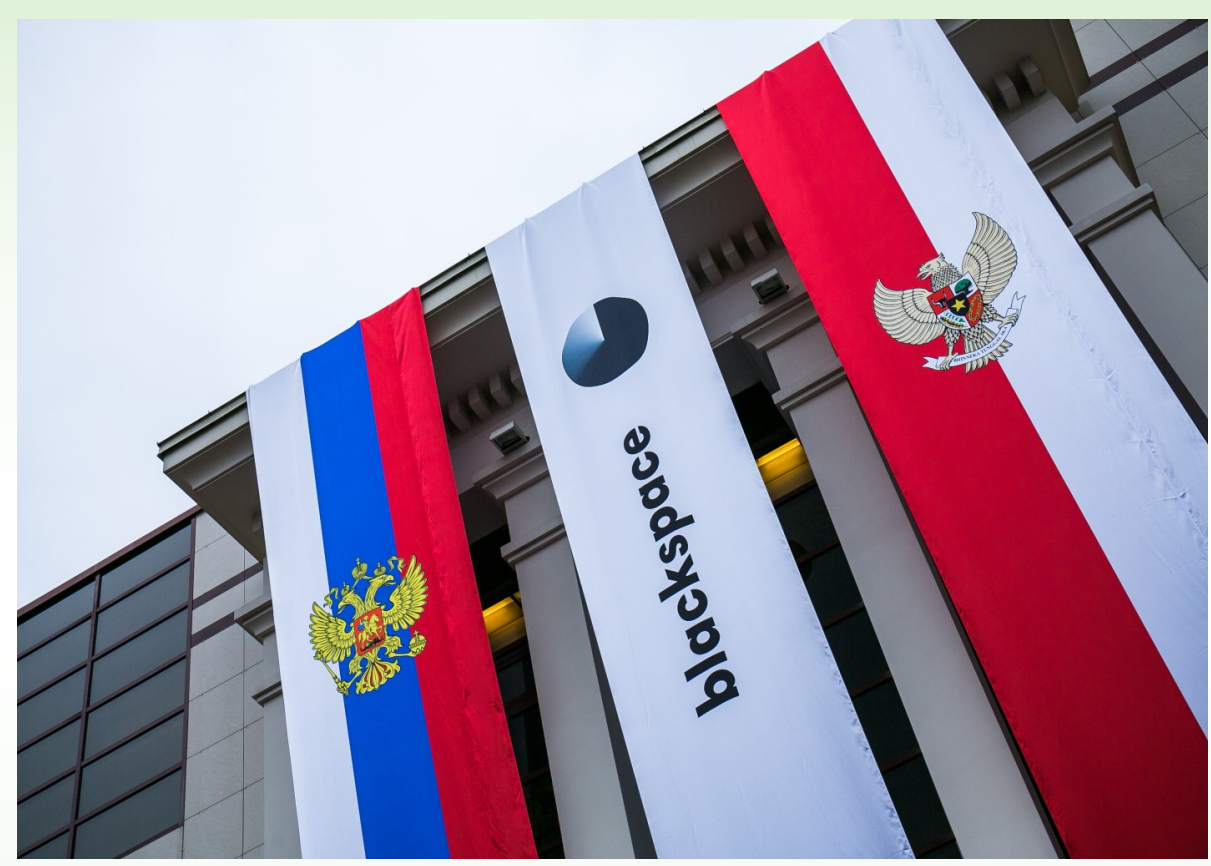

Indonesia mendapat tekanan yang kuat dari pihak Belanda.

Namun kemudian tepatnya tanggal 24 Desember 1949, Pemerintah Uni Soviet menerima pesan secara resmi mengenai kesepakatan yang diambil antara pemerintah Belanda dan Indonesia. Hal ini membuka ruang untuk melanjutkan kesepakatan yang dibuat antara Indonesia dan Uni soviet yang ditindaklanjuti oleh Menteri Luar negeri Uni Soviet Andrei Vyshinsky dan mengirimkan telegram kepada perdana Menteri dan Menteri Luar Negeri RI Mohammad Hatta yang berbunyi:

"Atas nama Pemerintah Uni Soviet, saya dengan hormat menginformasikan kepada anda, sejak pengakuan kedaulatan Republik Indonesia pada 27 Desember 1949 di Den Haag, Belanda
Pemerintah Uni Soviet memutuskan mengakui kedaulatan dan kemerdekaan Republik Indonesia dan akan membangun hubungan diplomatik dengan Indonesia."

Catatan sejarah tersebut menandakan bahwa hubungan Rusia dan Indonesia telah dimulai. Namun keadaan berlangsung lambat, dan bahkan sampai tahun 1954, pertukaran duta besar belum dilakukan antara dua negara tersebut. Pada Tahun 1956, terjadi kunjungan pertama ke Uni Soviet yang dilakukan oleh Presiden RI Pertama Soekarno, yang kemudian melahirkan kesepakatan perdagangan pertama kedua negara.

Walaupun terdapat perbedaan politik antara keduanya terutama pada perbedaan sistem ekonomi kedua negara, tetapi perbedaan 
tersebut tidak menghalangi kuatnya keinginan kedua negara untuk menjalin hubungan yang kuat. Kemudian disusul kunjungan dari pihak Uni Soviet di tahun 1957 yang dilakukan oleh Ketua Dewan Tertinggi Uni Soviet (USSR Supreme Soviet) Klim Voroshilov ke Indonesia. Kunjungan tersebut merupakan angin segar bagi Indonesia, selain meningkatkan hubungan kerjasama antara kedua negara yang sudah terjalin sebelumnya. Saat itu Indonesia membutuhkan bantuan terkait reformasi dan modernisasi angkatan bersenjata. Bahkan kemudian Indonesia malah mendapatkan lebih dari itu terutama di bidang teknologi dan pengetahuan.

Menurut Fahrurodji, hubungan kultural RusiaIndonesia terjalin mendahului hubungan diplomatik formal Uni soviet-Indonesia. Hubungan ini tumbuh dan berkembang dalam kenyataan perubahan sistem pemerintah hingga terbentuknya Uni Soviet dan pembentukan Indonesia sebagai bangsa. Artinya telah terjadi hubungan kultural diantara dua bangsa, pada saat kedua negara itu, Soviet dan Indonesia, belum terbentuk secara konkret (Fahrurodji, 2017: 123).

Sampai saat ini, hubungan yang terjalin antara negara Indonesia dan Rusia masih terjaga dengan baik. Bahkan Presiden RI Joko Widodo pada tahun 2016 mengadakan kunjungan ke Rusia dan menindaklanjuti hubungan bilateral antar kedua negara. Kemudian dilanjutkan dengan kunjungan Menteri Luar Negeri Indonesia, Retno LP Marshudi ke Moscow pada Maret 2018, dan disambut baik oleh Menlu Sergey Lavrov, serta mengakui bahwa hubungan bilateral antara keduanya sudah mencapai level kemitraan strategis, yakni pada bidang ekonomi, perdagangan, militer, dan kemanusiaan.

Saat ini Indonesia dan Rusia merupakan negara yang menjunjung tinggi nilai toleransi dan demokrasi. Walaupun bentuk pemerintahannya berbeda, tetapi memiliki persamaan sebagai negara multikultural dalam kawasan negara yang plural atau majemuk. Kemajemukan memiliki dua implikasi yang kontradiktif, di satu sisi kemajemukan tersebut menjadi karakteristik dan daya tarik sendiri bagi suatu bangsa, tetapi juga menjadi sebuah ancaman bagi integrasi bangsa yang mendorong pada disintegrasi. Kemunculan gerakan separatisme di masing-masing negara tersebut merupakan sebuah ujian dalam mempertahankan keutuhan sebuah bangsa.

Dampak kemajemukan masyarakat menimbukan gejolak timbulnya politik identitas pada masing-masing negara. Di Indonesia sebagaimana pendapat Syafii Ma'arif, politik Identitas lebih terkait pada etnisitas, agama, ideologi dan kepentingan-kepentingan lokal yang diwakili para elit politik dengan artikulasinya masing-masing, yang berdampak pada timbulnya gerakan pemekaran daerah (Maarif, 2012: 55-100). Isuisu tentang keadilan dan pembangunan daerah menjadi isu politik sentral, sehingga lebih banyak dipengaruhi oleh ambisi para elit lokal untuk tampil sebagai pemimpin. Implikasi negatifnya dapat menimbulkan upaya disintegrasi bangsa dan gerakan separatisme. Berbeda halnya Rusia, politik identitas di Rusia lebih mengarah kepada upaya tuntutan otonomi murni pada masing-masing wilayah yang dilandasi oleh adanya perbedaan ras dan kultur serta agama. Seperti pada kasus Chechnya yang hingga saat ini masih menjadi polemik besar.

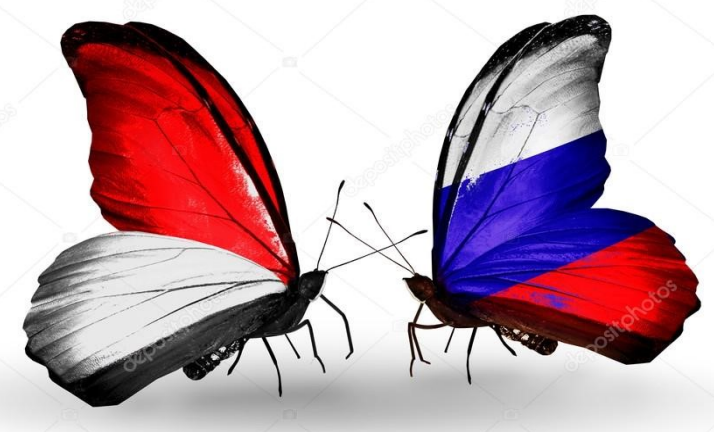

Karenanya, hubungan bilateral antar kedua negara yang dilandasi sejarah pertemanan yang baik antara keduanya, menimbulkan komunikasi politik yang efektif. Masing-masing negara akan saling bertukar pengalaman dalam menghadapi dilema politik identitas di negaranya masing-masing, sehingga gerakan tuntutan massa berbaju politik identitas tidak berlanjut pada gerakan separatisme yang merusak kedaulatan bangsa.[]

\section{Pustaka Acuan:}

*Penulis adalah dosen tetap FAI Universitas Ibn Khaldun, Bogor Jawa Barat, sekaligus mahasiswi program Ph.D Kazan Federal University, Russia.

Maarif, Ahmad Syafii, Politik Identitas dan Masa Depan Pluralisme Kita, (Jakarta: Democracy Project, 2012).

Fahrurodji, Ahmad, "Dari Druzhba Ke Mirnoye Sosushyestvovaniye: Diplomasi Uni Soviet-Indonesia dalam Era Stalin dan Kruschev, 1945-1964," dalam Jurnal Sejarah, Vol. 1, No. 1 (2017).

'Adalah; Buletin Hukum dan Keadilan merupakan berkala ilmiah yang diterbitkan oleh Pusat Studi Konstitusi dan Legislasi Nasional (POSKO-LEGNAS), Fakultas Syariah dan Hukum UIN Syarif Hidayatullah Jakarta.

Penasehat: Prof. Dr. H. Abdul Ghani Abdullah, SH., Prof. Dr. H. A Salman Maggalatung, SH., MH. Pemimpin Redaktur: Indra Rahmatullah, Tim Redaktur: Nur Rohim Yunus, Fathuddin, Mara Sutan Rambe, Muhammad Ishar Helmi, Erwin Hikmatiar. Penyunting: Latipah, Siti Nurhalimah. Setting \& Layout: Siti Romlah 